\title{
Protein profile and physicochemical characteristics of meat of lambs fed diets supplemented with rapeseed oil, fish oil, carnosic acid, and different chemical forms of selenium
}

\author{
Wiesław Przybylski ${ }^{1}$, Elżbieta Żelechowska ${ }^{1}$, Marian Czauderna ${ }^{2}$, Danuta Jaworska ${ }^{1}$, \\ Katarzyna Kalicka ${ }^{1}$, and Krzysztof Wereszka ${ }^{2}$ \\ ${ }^{1}$ Warsaw University of Life Sciences, Faculty of Human Nutrition and Consumer Sciences, \\ 02-776 Warszawa, Poland \\ ${ }^{2}$ The Kielanowski Institute of Animal Physiology and Nutrition - Polish Academy of Sciences, \\ 05-110 Jabłonna, Poland \\ Correspondence to: Wiesław Przybylski (wieslaw_przybylski@sggw.pl)
}

Received: 8 May 2016 - Revised: 1 April 2017 - Accepted: 15 April 2017 - Published: 15 May 2017

\begin{abstract}
The objective of this study was to evaluate the physicochemical characteristics of the longissimus muscle of lambs fed a control diet containing $3 \%$ rapeseed oil (RO) (group I); an experimental diet with $2 \% \mathrm{RO}$ and $1 \%$ fish oil (FO) (group II); or experimental diets with coupled addition of $2 \% \mathrm{RO}, 1 \% \mathrm{FO}$, and $0.1 \%$ carnosic acid (CA) (group III) without/with $0.35 \mathrm{ppm} \mathrm{Se}$ as selenized yeast (SeY) (group IV) or selenate ( $\mathrm{SeVI}$ as sodium selenate, $\mathrm{Na}_{2} \mathrm{SeO}_{4}$ ) (group V). The results showed that dietary $\mathrm{FO}$ or $\mathrm{SeVI}$ affected the ultimate $\mathrm{pH}$ and meat color in comparison to lambs fed the control diet. The differences noted between diets in the case of muscle tissue were as follows: myosin HC (heavy chain) and LC1 (light chain), $150 \mathrm{kDa}, \alpha$-actinin, $60 \mathrm{kDa}$, and TnT (troponin T), $30 \mathrm{kDa}$ protein. The addition of FO to lamb diets resulted in a lower content of $30 \mathrm{kDa}$ proteins, which are indicators of proteolysis. Considering the protein profile of drip loss, results showed effects of dietary administration of $\mathrm{FO}, \mathrm{CA}$, and $\mathrm{Se}$ (as $\mathrm{SeY}$ and $\mathrm{SeVI}$ ) on the abundance of the following sarcoplasmic proteins: AMPDA (AMP deaminase), PGM (phosphoglucomutase), PK/PGI (pyruvate kinase/phosphoglucose isomerase), CK/PGAK (creatine kinase/phosphoglycerate kinase), ALD (aldolase), LDH (lactate dehydrogenase), PGAM (phosphoglycerate mutase), and TPI (triosephosphate isomerase). The lower content of TPI (in group II with comparison to groups III-V) and PGAM (in group II with comparison to group I and III) could be due to a higher ultimate $\mathrm{pH}$ in the group with FO addition, whereas lower contents of CK/PGAK, ALD, and $\mathrm{LDH}$ were attributed to Se addition. In comparison to the control diet, all experimental diets without SeVI decreased the content of the sum of all assayed amino acids ( $\sum$ AAs), indispensable amino acids ( $\sum$ IAAs), and dispensable amino acids ( $\sum$ DAAs) in the muscle. The highest ratios of $\sum$ IAAs to $\sum$ DAAs and $\sum$ IAAs to $\sum$ AAs were found in the muscle of lambs fed the diet containing RO, FO, and CA. The FO-supplemented diet with $\mathrm{CA}$ and $\mathrm{SeVI}$ increased the abundance of methionine in the muscle in comparison to the control diet and the FO-supplemented diet without/with CA.
\end{abstract}




\section{Introduction}

The quality of meat has become an important issue in recent years. Consumers often understand quality as visual and sensory properties as well as the microbial safety of meat. Nevertheless, meat quality can be determined in a more unbiased way by evaluating such properties of meat as chemical composition, $\mathrm{pH}$ value, tenderness, water-holding capacity, and color. Those properties can, however, be affected by genetic and environmental factors (Ramírez-Retamal et al., 2014).

One of the factors that determine the quality of lamb meat is the type of feed administered to animals. The nutritional characteristics of a diet (contents of energy, protein, fatty acids, vitamins, and minerals) affect value-added properties of meat and, thereby, its quality (Luciano et al., 2009b; Aouadi et al., 2014; Schiller et al., 2015). Recently, special attention has been paid to lamb diet supplementation with phenolic compounds (especially carnosic acid) and seleno-compounds that have the ability to modify the ruminal microbiota profile and, hence, fatty acid metabolism in the rumen (Del Razo-Rodriguez et al., 2013; Jordan et al., 2013; Kišidayová et al., 2014; Cobellis et al., 2016). Recent studies have shown a positive effect of carnosic acid (CA; a constituent of rosemary) on the improvement of meat quality, including either extension of the shelf life of lamb meat or slowing down meat discoloration (Morán et al., 2012b, 2013). Dietary CA has a significant effect upon the biosynthesis of ruminal volatile fatty acids (Miltko et al., 2016) and may beneficially modify the profile of fatty acids (FAs) in lambs' muscles. Due to its antioxidant properties, it may protect polyunsaturated FAs (PUFAs), especially longchain PUFAs (LPUFAs), from lipid peroxidation in muscles (Morán et al., 2012a, b, 2013) and stabilize the oxidative status of edible parts of farm animals (Ponnampalam et al., 2012; Aouadi et al., 2014). Sparse research is, however, available regarding the effect of CA on proteolysis of muscle protein in lamb meat during ageing. However, the influence of Se supplementation on lamb meat quality was only determined based on changes of $\mathrm{pH}$, drip and cooking losses, meat color, and oxidative stability (Vignolla et al., 2009), as well as shelf life of packaged meat (Ripoll et al., 2011). To our knowledge there are no publications that discuss the coupled dietary effect of fish oil (FO), CA, and Se on meat quality characteristics.

Having considered the above facts, we expected that dietary CA, selenate (SeVI), and selenized yeast (SeY) would change the biohydrogenation yield of unsaturated FAs (UFAs) in the rumen and consequently the accumulation of PUFAs, particularly conjugated isomers of linoleic acid (CLA) and their precursors and metabolites, in lamb muscles. Moreover, considering our previous studies (Wąsowska et al., 2006), we expected that dietary FO would reduce the biohydrogenation of UFAs in the rumen and consequently would increase the concentration of UFAs in muscles. The concentration changes of UFAs in muscles will exert influence on physicochemical characteristics of lamb muscles.

Therefore, the first aim of our study was to compare effects of $1 \% \mathrm{FO}$ (rich in pro-oxidizing LPUFAs) added to the diet including $2 \%$ rapeseed oil (RO) (the experimental diet) with the control diet containing $3 \% \mathrm{RO}$ on the protein profile and physicochemical characteristics of the longissimus muscle of lambs. In our investigation, the diet with only $3 \% \mathrm{RO}$ was considered as the control diet as it does not contain prooxidizing LPUFAs as well as antioxidants (i.e., CA, SeY or $\mathrm{SeVI}$ ).

The second objective of our study was to investigate effects of the addition of CA with or without different chemical forms of $\mathrm{Se}$ (as $\mathrm{SeY}$ or $\mathrm{SeVI}$ ) to the diet including $\mathrm{RO}$ and FO on the protein profile and physicochemical characteristics of the longissimus muscle of lambs. The effects of these experimental diets were compared with effects of the FO-supplemented diet containing RO as well as with the diet with only RO (the control diet). The last objective of our study was to compare the influence of the addition of SeY to the diet containing RO, FO, and $\mathrm{CA}$ with the addition of $\mathrm{SeVI}$ to the diet including $\mathrm{RO}, \mathrm{FO}$, and $\mathrm{CA}$ on the protein profile and physicochemical characteristics of the longissimus muscle of lambs.

\section{Material and methods}

\subsection{Animals, housing, diets, and experimental design}

Thirty male Corriedale lambs with an average body weight (BW) of $30.5 \pm 2.6 \mathrm{~kg}$ at the beginning of the experiment were individually penned and divided into five dietary groups (groups I-V) of six animals each according to their initial BW, so that the average initial BWs of lambs were similar between the groups. The study protocol was approved by the Third Local Commission of Animal Experiment Ethics at the University of Life Sciences, Ciszewskiego 8, 02-786 Warsaw (Poland). During a 3-week preliminary period, the animals were given free access to the chosen feed (the standard concentrate-hay diet with vitamins and mineral premix) (Jaworska et al., 2016). In the 3-week preliminary period, the lambs from group I (the control group) were fed the diet enriched with $3 \%$ RO (the control diet), whereas the lambs from groups II-V (the experimental groups) were fed the diet enriched with $2 \%$ RO and $1 \%$ odorless fish oil (FO) (FO diet) (Jaworska et al., 2016). The energy content of FO and RO was 36.8 and $37.0 \mathrm{MJ} \mathrm{kg}^{-1}$ oil, respectively. The fatty acid profiles of dosed FO and $\mathrm{RO}$ as well as other ingredients in the diet were presented in a previous publication (Rozbicka-Wieczorek et al., 2016). The diet allowance was changed weekly according to body weight of lambs and supplied as two equal meals at 07:30 and 16:00 CET (central European time; UTC + 01) each day to ensure free access to the feed. Whole served portions of meals were eaten by the animals. Fresh drinking water was available ad libitum. 
The lambs were slaughtered at the end of the 35-day experiment (Jaworska et al., 2016). After slaughter the carcasses were chilled in a cooling room and held in the cold storage at $4{ }^{\circ} \mathrm{C}$. Longissimus muscle was removed and weighed; all muscle samples were stored in sealed tubes at $-32^{\circ} \mathrm{C}$ until analysis.

Selenized yeast (Se-Saccharomyces cerevisiae) was donated by Sel-Plex (Alltech In., Nicholasville, KY, USA). About $83 \%$ of the Se content of selenized yeast (SeY) represents $\mathrm{Se}$ in the form of seleno-methionine incorporated into the proteins of Saccharomyces cerevisiae; the chemical composition of SeY was presented in a previous publication (Czauderna et al., 2009). SeVI as sodium selenate $\left(\mathrm{Na}_{2} \mathrm{SeO}_{4}\right)$ was purchased from Sigma-Aldrich (St. Louis, MO, USA).

CA was purchased from Hunan Geneham Biomedical Technology Ltd. (Changsha, Hunan, China). RO and odorless FO were supplied by AGROSOL (Pacanów, Poland).

\subsection{Meat quality traits and biochemical analysis}

Meat quality parameters were evaluated in the samples taken from the longissimus muscle. The samples were collected at the height of the last rib after the carcasses had been cooled for $24 \mathrm{~h}$ after the slaughter. At the meat processing plants, the $\mathrm{pH}$ value was measured $3\left(\mathrm{pH}_{3}\right), 24\left(\mathrm{pH}_{24}\right)$, and $48 \mathrm{~h}$ $\left(\mathrm{pH}_{48}\right)$ after slaughter with a WTW 330i pH meter (Weilheim, Germany) with special electrodes (SenTix ${ }^{\circledR}$ SP number 103645), enabling $\mathrm{pH}$ measurement directly in meat. The samples were transported in ice-chilled polystyrene refrigerators at $4{ }^{\circ} \mathrm{C}$. All remaining analyses were conducted at the laboratory.

Meat color was measured $48 \mathrm{~h}$ post mortem according to the CIE $L^{*} a^{*} b^{*}$ system using a CR310 Minolta Chroma meter with a $D_{65}$ light source (Osaka, Japan). Loin chops (length of $2 \mathrm{~cm}$ ) were cut and bloomed for $1 \mathrm{~h}$ at $4{ }^{\circ} \mathrm{C}$ with no surface covering prior to color measurements (in triplicate).

The drip loss percentage was determined 24 and $48 \mathrm{~h}$ after slaughter according to Prange et al. (1977). During that time, longissimus muscles were placed in a plastic bag and kept at $4{ }^{\circ} \mathrm{C}$ for the drip loss to appear. The drip loss was collected into Eppendorf tubes for glucose and lactate measurements. Muscle glucose (mmol) was determined with an Accu-Check Active $^{\circledR}$ glucometer (Accu-Check Sensor Comfort ${ }^{\circledR}$, Roche, Germany), which is normally employed for measuring blood glucose in humans. Reactive strips were used for the quantitative determination of glucose with the glucometer in the value range between 0.6 and $33.3 \mathrm{mmol}$. The test results were obtained $60 \mathrm{~s}$ after placing a drop with an approximate volume of $20 \mu \mathrm{L}$ of drip loss on a reactive strip.

Lactic acid (mmol) was measured with the strip method using Accutrend ${ }^{\circledR}$ lactate type 3012522 strips (Roche, Mannheim, Germany). Samples were diluted with distilled water $(1: 10)$ to reach lactate concentration in the following range: 8.7 to $26 \mathrm{mM}$. The test results were also obtained $60 \mathrm{~s}$ after placing a drop with an approximate volume of $20 \mu \mathrm{L}$ of diluted drip loss on a reactive strip. Then, the results were converted into the concentration in undiluted drip loss. The measurements were made twice.

Muscle glycolytic potential (GP) was calculated according to the formula by Monin and Sellier (1985) summing glucose and lactic acid and expressed as mmol lactic acid $\mathrm{L}^{-1}$ fresh (hot) muscle tissue.

Drip and meat samples were frozen at $-80^{\circ} \mathrm{C}$ until subsequent analysis.

\subsection{Sodium dodecyl sulfate polyacrylamide gel electrophoresis (SDS-PAGE)}

SDS-PAGE of drip loss and muscular tissue was performed according to the method of Bollag and Edelstein (1999) using the STANDARD system (Kucharczyk TE, Poland). Proteins were resolved on a $12 \%$ separation gel and $5 \%$ stacking gel. Myofibrillar proteins were extracted from $20 \mathrm{mg}$ of muscle, homogenized with $800 \mu \mathrm{L}$ of a Tris- $\mathrm{HCl}$ buffer ( $\mathrm{pH}$ 6.8) containing $0.375 \mathrm{M}$ 2-mercaptoethanol, $3 \% \mathrm{SDS}, 8 \mathrm{M}$ urea, and $2 \mathrm{M}$ thiourea. Muscle protein content was determined as total nitrogen using the AOAC method number 928.08 (1974). The content of soluble proteins in the drip loss was determined using the Biuret procedure (Gornall et al., 1949). Мyofibrillar and soluble proteins from the drip loss were dissolved $(1 / 1, v / v)$ in Tris-HCl sample buffer ( $\mathrm{pH}$ 6.8) containing $0.375 \mathrm{M}$ 2-mercaptoethanol, $3 \%$ SDS, $8 \mathrm{M}$ urea, $2 \mathrm{M}$ thiourea, and $0.05 \%$ bromophenol blue. The mixture was then heated for $3 \mathrm{~min}$ at $95^{\circ} \mathrm{C}$ and $10 \mu \mathrm{L}$ of the mixture was then placed in each well. Protein bands were stained with Coomassie brilliant blue R250 (Sigma-Aldrich, St. Louis, Missouri, USA) dissolved in water, methanol, and acetic acid ( $4: 5: 1, v / v / v)$ and destained using a solution of methanol, water, and acetic acid $(1: 8: 1, v / v / v)$. Image analysis and quantification were performed using GelScan v. 1.45 software (Kucharczyk TE, Poland).

\subsection{Chromatographic analysis of amino acids in the Longissimus muscle}

Longissimus muscle samples (about 400-500 mg fresh muscle) were hydrolyzed with $50 \mathrm{~mL}$ of $6 \mathrm{M} \mathrm{HCl}$ at $104 \pm 2{ }^{\circ} \mathrm{C}$ for $20 \mathrm{~h}$ in sealed tubes. After cooling, the hydrolysates were filtered through filter paper and then a filter residue was washed three times with $\sim 10 \mathrm{~mL}$ of water. Hydrochloric acid was removed from the filtrates in a vacuum rotary evaporator. Ten milliliters of water were added to the residue and then evaporated to dryness again in vacuum to remove residues of $\mathrm{HCl}$. The evaporating procedure was repeated twice. The residues were stored at $-18^{\circ} \mathrm{C}$ when not in use. The residue was re-dissolved in $1 \mathrm{~mL}$ of $0.4 \mathrm{M}$ borate buffer (pH 9.9). The resulting solution (I) was used for the derivatization procedure as below.

- Preparation of the derivatizing reagent: $75 \mathrm{mg}$ of $o$ phthaldialdehyde was dissolved in $4.5 \mathrm{~mL}$ of methanol 
and $0.5 \mathrm{~mL}$ of $0.4 \mathrm{M}$ borate buffer. Next, $70 \mu \mathrm{L}$ of ethanethiol was added and the resulting solution was mixed. Methanol, ethanethiol, $o$-phthaldialdehyde, and all amino acids used were from Sigma-Aldrich (St. Louis, MO, USA).

- Derivatization procedure: to $20 \mu \mathrm{L}$ of the resulting solution (I), $1 \mathrm{~mL}$ of the derivatizing reagent and $10 \mu \mathrm{L}$ of $1 \mathrm{M} \mathrm{NaOH}$ were added. The contents were mixed and reacted for $3 \mathrm{~min}$ at room temperature. At the end of the 3 min derivatization period, the processed samples were injected onto the Nova Pak $\mathrm{C}_{18}$ column ( $4 \mu \mathrm{m}, 250 \times 4.6 \mathrm{~mm}$, I.D.; Milford, MA, USA). Amino acid contents in processed muscle samples were chromatographically determined according to Czauderna et al. (2002).

- Chromatographic equipment: a Waters Alliance separation module (model 2690; Milford, MA, USA) with a Waters fluorescence detector (model 474; Milford, MA, USA) was used for the gradient elution systems (Czauderna et al., 2002).

\subsection{Data analysis}

All values were reported as the means \pm standard deviation (SD) (Tables 1-3) or as the means (Table 4). The normality of distribution of all analyzed traits was checked with the Shapiro-Wilk test before statistical analyses. A one-way analysis of variance of the type of the diet as a fixed effect was performed. The significance of differences between means (at the level of $P_{\alpha} \leq 0.05$ and $P_{\alpha} \leq 0.01$ ) of different groups was estimated by using Tukey's test. The simple Pearson linear correlations between measured traits were calculated. The significance of correlations was tested by means of an $F$ test. Statistical analysis was conducted with Statistica 10 software (StatSoft, Inc., 2011).

\section{Results and discussion}

\subsection{Effect of lamb diets on meat quality characteristics}

The analysis of the obtained data showed significant differences in $\mathrm{pH}$ value of meat $48 \mathrm{~h}$ after slaughter. Samples of meat from group I (fed with $3 \%$ rapeseed oil) were characterized by the lowest value of $\mathrm{pH}_{48}$, whereas samples from group II (fed with $1 \%$ addition of fish oil, FO) had the highest $\mathrm{pH}_{48}$ (Table 1). No significant differences were observed between other groups. It should be noted that $\mathrm{pH}$ values do not exactly reflect the level of lactate and glycolytic potential at slaughter time (Table 1). According to Van Laack et al. (2001), this inconsistency between ultimate $\mathrm{pH}$ and lactate levels could be explained by the buffering capacity of muscles.

With respect to high ultimate $\mathrm{pH}$ observed in group II, similar findings were reported by Najafi et al. (2012) for meat from goat kids fed with fish oil. Nevertheless, $\mathrm{pH}_{48}$ values recorded in groups fed with CA and SE (groups III, IV, and $\mathrm{V}$ ) were intermediate between group RO (group I) and FO (group II). A study by Morán et al. (2012b) showed significant and lower $\mathrm{pH}_{24}$ in meat of lambs fed CA $\left(0.6 \mathrm{~g} \mathrm{~kg}^{-1}\right)$ compared to the control group, and no respective differences in the group with CA dose of $1.2 \mathrm{~g} \mathrm{~kg}^{-1}$. No significant differences between ultimate $\mathrm{pH}$ of lambs fed CA in comparison to the control group were found in studies by Bañón et al. (2012) and Ortuño et al. (2014). Also, no effect of Se level or source on meat $\mathrm{pH}$ was stated in the studies of Vignola et al. (2009) and Skřivanová et al. (2007).

Color parameters differed significantly between groups of animals. The lightest meat was observed in groups III and IV (containing FO, CA, and SeY in the diet). The higher lightness of meat was also stated in the group of lambs fed the diet containing $\mathrm{CA}$ in a study conducted by Morán et al. (2012a, b) and Ortuño et al. (2014), while no differences were reported by Bañón et al. (2012) and Aouadi et al. (2014). Darker meat $\left(P_{\alpha} \leq 0.05\right)$ was observed in the group with RO (group I), with inorganic Se (group V) and with fish oil (group II). The results achieved by Nute et al. (2007) also showed that FO in lamb diet reduced the intensity of meat color. While Ponnampalam et al. (2012) stated that the content of highly oxidizable PUFAs in muscle tissues has no major role in maintenance of redness at days 34 of retail display, and that vitamin $\mathrm{E}$ and heme iron contents are important. Considering $a^{*}$ and $b^{*}$ color parameters, the meat from group I was more red and yellow. Results in Table 1 show also that the addition of FO and SeVI to the diet decreased redness and yellowness of meat, while supplementation of lamb diet with $\mathrm{CA}$ and $\mathrm{SeY}$ increased values of $a^{*}$ and $b^{*}$ coordinates of color $\left(P_{\alpha} \leq 0.05\right)$ (Table 1). It is worth noting that studies of many authors have shown no effects of diets containing CA (Bañón et al., 2012; Morán et al., 2012b; Aouadi et al., 2014; Ortuño et al., 2014) or Se on redness and yellowness of veal and lamb meat (Skřivanová et al. 2007; Vignolla et al., 2009) as well as on retarding color deterioration. These differences in the presented results may be due to the combined effect of FO and SeY added to diet. However, Taylor et al. (2008) found that meat from cattle fed selenium-enriched diet tended to have a higher average values of $a^{*}$ and $b^{*}$ during 12 days of exposition in comparison to the control group. Also, Zhan et al. (2007) showed that diet supplementation with Se increased the Hunter $a^{*}$ value, but more in the selenomethionine-treated group than in the sodium selenite-treated group. Furthermore, as it was stated by Caputi-Jambrenghi et al. (2005), $\alpha$-tocopherol acetate stabilized meat color more efficiently than rosemary extract did. The same result was observed in gluteus medius muscle upon diet supplementation with low doses of CA and vitamin $\mathrm{E}\left(0.6 \mathrm{~g} \mathrm{~kg}^{-1}\right)$. Only the highest dose of carnosic acid $\left(1.2 \mathrm{~g} \mathrm{~kg}^{-1}\right)$ tended to show a similar effect to vitamin E. But Ortuño et al. (2014) found that a rosemary diterpenes extract significantly delayed lamb meat discoloration at 11 and/or 
Table 1. Effect of different diets on quality characteristics of the longissimus muscle of lambs.

\begin{tabular}{|c|c|c|c|c|c|}
\hline \multirow[t]{4}{*}{ Variable } & \multicolumn{5}{|c|}{ Group } \\
\hline & I & II & III & IV & V \\
\hline & \multicolumn{5}{|c|}{ Diet } \\
\hline & Control & $+1 \% \mathrm{FO}$ & $+1 \% \mathrm{FO}+0.1 \% \mathrm{CA}$ & $\begin{array}{l}+1 \% \mathrm{FO}+0.1 \% \mathrm{CA} \\
+0.35 \mathrm{ppm} \mathrm{Se} \\
\text { as SeY }\end{array}$ & $\begin{array}{l}+1 \% \mathrm{FO}+0.1 \% \mathrm{CA} \\
+0.35 \mathrm{ppm} \text { Se as SeVI }\end{array}$ \\
\hline $\mathrm{pH}_{3}$ & $\begin{array}{l}6.77 \\
\pm 0.04\end{array}$ & $\begin{array}{l}6.73 \\
\pm 0.19\end{array}$ & $\begin{array}{l}6.62 \\
\pm 0.20\end{array}$ & $\begin{array}{l}6.73 \\
\pm 0.04\end{array}$ & $\begin{array}{l}6.66 \\
\pm 0.25\end{array}$ \\
\hline $\mathrm{pH}_{24}$ & $\begin{array}{l}5.47 \\
\pm 0.06\end{array}$ & $\begin{array}{l}5.65 \\
\pm 0.04\end{array}$ & $\begin{array}{l}5.71 \\
\pm 0.48\end{array}$ & $\begin{array}{l}5.47 \\
\pm 0.07\end{array}$ & $\begin{array}{l}5.63 \\
\pm 0.06\end{array}$ \\
\hline $\mathrm{pH}_{48}$ & $\begin{array}{l}5.40^{\mathrm{a}} \\
\pm 0.02\end{array}$ & $\begin{array}{l}5.60^{\mathrm{b}} \\
\pm 0.11\end{array}$ & $\begin{array}{l}5.51^{\mathrm{ac}} \\
\pm 0.04\end{array}$ & $\begin{array}{l}5.48^{\mathrm{ac}} \\
\pm 0.03\end{array}$ & $\begin{array}{l}5.50^{\mathrm{ac}} \\
\pm 0.05\end{array}$ \\
\hline Meat color: $L^{*}$ & $\begin{array}{l}43.97^{\mathrm{a}} \\
\pm 1.49\end{array}$ & $\begin{array}{l}43.53^{\mathrm{a}} \\
1.87\end{array}$ & $\begin{array}{l}46.63^{b} \\
\pm 2.54\end{array}$ & $\begin{array}{l}46.63^{b} \\
\pm 1.26\end{array}$ & $\begin{array}{l}43.26^{\mathrm{a}} \\
\pm 2.20\end{array}$ \\
\hline$a^{*}$ & $\begin{array}{l}23.26^{\mathrm{a}} \\
\pm 1.61\end{array}$ & $\begin{array}{l}19.29^{b} \\
\pm 0.82\end{array}$ & $\begin{array}{l}20.89^{c} \\
\pm 1.34\end{array}$ & $\begin{array}{l}20.18^{b c} \\
\pm 1.34\end{array}$ & $\begin{array}{l}17.59^{b c} \\
\pm 0.81\end{array}$ \\
\hline$b^{*}$ & $\begin{array}{l}9.55^{\mathrm{c}} \\
\pm 1.51\end{array}$ & $\begin{array}{l}4.30^{\mathrm{a}} \\
\pm 0.70\end{array}$ & $\begin{array}{l}7.30^{\mathrm{b}} \\
\pm 3.03\end{array}$ & $\begin{array}{l}6.74^{\mathrm{b}} \\
\pm 1.98\end{array}$ & $\begin{array}{l}4.17^{\mathrm{a}} \\
\pm 0.41\end{array}$ \\
\hline Drip loss 24 h (\%) & $\begin{array}{l}2.57 \\
\pm 1.87\end{array}$ & $\begin{array}{l}1.56 \\
\pm 0.70\end{array}$ & $\begin{array}{l}1.92 \\
\pm 0.38\end{array}$ & $\begin{array}{l}1.93 \\
\pm 0.40\end{array}$ & $\begin{array}{l}1.92 \\
\pm 0.83\end{array}$ \\
\hline Drip loss $48 \mathrm{~h}(\%)$ & $\begin{array}{l}4.23 \\
\pm 1.90\end{array}$ & $\begin{array}{l}3.17 \\
\pm 1.00\end{array}$ & $\begin{array}{l}3.31 \\
\pm 0.30\end{array}$ & $\begin{array}{l}3.09 \\
0.48\end{array}$ & $\begin{array}{l}3.38 \\
\pm 0.81\end{array}$ \\
\hline Glucose $\left(\mathrm{mmol} \mathrm{L}^{-1}\right)$ & $\begin{array}{l}6.15 \\
\pm 1.37\end{array}$ & $\begin{array}{l}4.73 \\
\pm 1.30\end{array}$ & $\begin{array}{l}6.60 \\
\pm 1.71\end{array}$ & $\begin{array}{l}6.60 \\
\pm 1.08\end{array}$ & $\begin{array}{l}6.06 \\
\pm 1.35\end{array}$ \\
\hline Lactate $\left(\mathrm{mmol} \mathrm{L}^{-1}\right)$ & $\begin{array}{l}92.50 \\
\pm 6.37\end{array}$ & $\begin{array}{l}86.50 \\
\pm 14.05\end{array}$ & $\begin{array}{l}89.17 \\
\pm 9.54\end{array}$ & $\begin{array}{l}87.17 \\
\pm 6.18\end{array}$ & $\begin{array}{l}77.00 \\
\pm 12.30\end{array}$ \\
\hline $\begin{array}{l}\text { Glycolytic potential } \\
\left(\mathrm{mmol} \mathrm{L}^{-1}\right)\end{array}$ & $\begin{array}{l}104.80 \\
\pm 7.12\end{array}$ & $\begin{array}{l}95.95 \\
\pm 16.45\end{array}$ & $\begin{array}{l}102.36 \\
\pm 11.07\end{array}$ & $\begin{array}{l}100.36 \\
\pm 4.47\end{array}$ & $\begin{array}{l}89.12 \\
\pm 11.94\end{array}$ \\
\hline
\end{tabular}

a, b, c - means with different superscripts in the same row differ significantly at $P_{\alpha} \leq 0.05$; FO - fish oil, CA - carnosic acid, SeY - the organic chemical form of selenium, SeVI - selenate.

14 days of storage. In turn, the effect of tannins on improving meat color stability of fresh lamb during extended refrigerated storage was shown by Luciano et al. (2009a). They demonstrated that tannin supplementation of lamb diet increased $a^{*}$ values and reduced $b^{*}$ values as well as resulted in a higher heme pigment content in the SM during refrigerated storage.

No significant differences were observed in glucose, lactate, and glycolytic potential contents and drip loss among dietary groups (Table 1). In relation to drip loss, in the study of Morán et al. (2012b), no significant differences were observed in water-holding capacity between control and groups supplemented with CA and vitamin E. Also, Skřivanová et al. (2007) and Vignola et al. (2009) demonstrated no effect of Se on natural drip loss in meat. In turn, Li et al. (2011) showed that increased levels of SeY decreased the drip loss in the muscle. Finally, Zhan et al. (2007) showed significantly reduced drip loss in Se-methionine-treated group in comparison to the control and the Na-selenite-treated group. These authors concluded that dietary Se-methionine contributed to a significant decrease in drip loss of the muscle by protecting membrane integrity.

The results showed that meat from lambs fed a diet with FO addition was characterized by higher $\mathrm{pH}_{48}$ and lesser lightness, redness, and yellowness. Similar results (regarding the indicated color parameters) were observed in the group fed with addition of FO, CA, and inorganic Se (the $\mathrm{V}$ diet, Table 1). Zhan et al. (2007) reported that organic Se did not seem to affect meat quality, but inorganic Se might have a detrimental effect on it.

Regarding CA addition to diets for lambs, it may be concluded that it changed the ultimate $\mathrm{pH}$ and color parameters of meat. According to Morán et al. (2012a, c) CA shows a lower antioxidant activity when compared to vitamin $\mathrm{E}$ but it seems to be useful in protecting meat from discoloration. Bañon et al. (2012) stated that dietary inclusion of rosemary clearly seems to be promising as a nutritional strategy for improving meat quality. In a study by Ortuño et al. (2014), dietary rosemary extract delayed lean and fat discoloration, odor deterioration and microbial spoilage. However, in the research by Aouadi et al. (2014), essential oils from a rose- 
Table 2. Effect of different diets on protein profile of the longissimus muscle of lambs after 7 days of ageing (\%).

\begin{tabular}{|c|c|c|c|c|c|}
\hline \multirow[t]{4}{*}{ Protein } & \multicolumn{5}{|c|}{ Group } \\
\hline & I & II & III & IV & $\mathrm{V}$ \\
\hline & \multicolumn{5}{|c|}{ Diet } \\
\hline & Control & $+1 \% \mathrm{FO}$ & $\begin{array}{l}+1 \% \mathrm{FO} \\
+0.1 \% \mathrm{CA}\end{array}$ & $\begin{array}{l}+1 \% \mathrm{FO}+0.1 \% \mathrm{CA} \\
+0.35 \mathrm{ppm} \mathrm{Se} \\
\text { as } \mathrm{SeY}\end{array}$ & $\begin{array}{l}+1 \% \mathrm{FO}+0.1 \% \mathrm{CA} \\
+0.35 \mathrm{ppm} \mathrm{Se} \\
\text { as SeVI }\end{array}$ \\
\hline \multirow[t]{2}{*}{ Myosin HC } & $22.33^{\mathrm{ab}}$ & $21.60^{\mathrm{ab}}$ & $23.10^{\mathrm{b}}$ & $20.37^{\mathrm{ac}}$ & $18.36^{\mathrm{c}}$ \\
\hline & \pm 1.69 & \pm 2.32 & \pm 2.83 & \pm 2.26 & \pm 1.38 \\
\hline \multirow[t]{2}{*}{$150 \mathrm{kDa}$} & $10.64^{\mathrm{a}}$ & $10.85^{\mathrm{a}}$ & $9.75^{\mathrm{ac}}$ & $7.49^{\mathrm{b}}$ & $8.42^{b c}$ \\
\hline & \pm 1.45 & \pm 1.52 & \pm 1.33 & \pm 0.94 & \pm 1.15 \\
\hline \multirow[t]{2}{*}{$\alpha$-actinin } & $7.20^{\mathrm{a}}$ & $6.46^{\mathrm{b}}$ & $6.79^{\mathrm{ab}}$ & $7.03^{\mathrm{a}}$ & $7.26^{\mathrm{a}}$ \\
\hline & \pm 0.68 & \pm 0.26 & \pm 0.59 & \pm 0.39 & \pm 0.27 \\
\hline \multirow[t]{2}{*}{$\mu$-calpain } & 2.09 & 2.16 & 2.25 & 2.38 & 2.48 \\
\hline & \pm 0.30 & \pm 0.49 & \pm 0.24 & \pm 0.36 & \pm 0.23 \\
\hline \multirow[t]{2}{*}{$80 \mathrm{kDa}$} & 2.29 & 2.23 & 2.13 & 2.65 & 2.68 \\
\hline & \pm 0.41 & \pm 0.88 & \pm 0.52 & \pm 1.27 & \pm 0.91 \\
\hline \multirow[t]{2}{*}{$75 \mathrm{kDa}$} & 3.59 & 4.34 & 4.01 & 4.12 & 4.25 \\
\hline & \pm 0.41 & \pm 0.55 & \pm 0.54 & \pm 0.43 & \pm 0.37 \\
\hline \multirow[t]{2}{*}{$60 \mathrm{kDa}$} & $4.32^{\mathrm{ab}}$ & $4.06^{\mathrm{a}}$ & $3.94^{\mathrm{a}}$ & $4.91^{\mathrm{bc}}$ & $5.30^{\mathrm{c}}$ \\
\hline & \pm 0.71 & \pm 0.68 & \pm 0.52 & \pm 0.53 & \pm 0.77 \\
\hline \multirow[t]{2}{*}{ Actinin } & 23.96 & 24.62 & 25.83 & 25.64 & 24.63 \\
\hline & \pm 1.39 & \pm 1.81 & \pm 1.35 & \pm 1.93 & \pm 1.07 \\
\hline \multirow[t]{2}{*}{ TnT } & $6.38^{\mathrm{ab}}$ & $6.11^{\mathrm{a}}$ & $4.99^{c}$ & $6.72^{\mathrm{b}}$ & $6.24^{\mathrm{ab}}$ \\
\hline & \pm 0.71 & \pm 0.38 & \pm 0.32 & \pm 0.41 & \pm 0.42 \\
\hline \multirow[t]{2}{*}{ Tropomyosin } & 6.82 & 6.45 & 5.68 & 6.64 & 6.42 \\
\hline & \pm 0.75 & \pm 0.54 & \pm 0.82 & \pm 1.43 & \pm 0.62 \\
\hline \multirow[t]{2}{*}{$33 \mathrm{kDa}$} & 4.56 & 4.23 & 3.84 & 4.34 & 3.84 \\
\hline & \pm 1.73 & \pm 0.37 & \pm 0.56 & \pm 0.64 & \pm 0.51 \\
\hline \multirow[t]{2}{*}{$30 \mathrm{kDa}$} & $1.78^{\mathrm{a}}$ & $1.04^{\mathrm{a}}$ & $1.93^{\mathrm{a}}$ & $2.05^{\mathrm{ab}}$ & $3.03^{\mathrm{b}}$ \\
\hline & \pm 1.21 & \pm 0.62 & \pm 0.65 & \pm 0.94 & \pm 0.76 \\
\hline \multirow[t]{2}{*}{ Myosin LC1 } & $2.67^{\mathrm{b}}$ & $4.09^{\mathrm{a}}$ & $4.22^{\mathrm{a}}$ & $3.77^{\mathrm{ab}}$ & $4.62^{\mathrm{a}}$ \\
\hline & \pm 1.24 & \pm 0.42 & \pm 0.31 & \pm 1.42 & \pm 0.70 \\
\hline \multirow[t]{2}{*}{ TnI } & 1.35 & 1.75 & 1.49 & 1.88 & 2.44 \\
\hline & \pm 0.96 & \pm 1.19 & \pm 1.11 & \pm 1.34 & \pm 0.84 \\
\hline
\end{tabular}

a, b, c - means with different superscripts in the same row differ significantly at $P_{\alpha} \leq 0.05$. TnT - troponin T; TnI - troponin I; LC1 - light chain of myosin; FO fish oil; CA - carnosic acid; SeY - the organic chemical form of selenium; SeVI - selenite.

mary extract were ineffective in preventing color deterioration.

\subsection{Effect of lamb diets on the proteolysis and profile of muscle proteins}

Table 2 shows the protein profile of muscle tissue in five lamb groups. Average values for all groups regarding contents of myosin, $\alpha$-actinin, $\mu$-calpain, actin, troponin $\mathrm{T}$ (TnT), tropomyosin, myosin LC1, troponin I (TnI), represented $21.2,6.9,2.3,24.9,6.1,6.4,3.9$, and $1.8 \%$, respectively. Kołczak et al. (2003) stated that the differences of the composition of meat protein depended on the age of the animal, type of muscle, and duration of chilled storage. The residual products of the proteolytic changes during meat maturation were divided into polypeptides with molecular weights between 60 and $78 \mathrm{kDa}$ and polypeptides with an approximate molecular weight of $30 \mathrm{kDa}$. The bands 76 and $78 \mathrm{kDa}$ are probably products of $\mu$-calpain autolysis (Bee et al., 2007; HuffLonergan and Lonergan, 2005, 2007). The $30 \mathrm{kDa}$ polypeptides are the products of post mortem proteolysis of TnT (Huff-Lonergan and Lonergan, 2005; Huff-Lonergan et al., 2010) and are used as indicators of proteolysis (Hopkins and Thompson, 2002; Santé-Lhoutellier et al., 2008). It should be mentioned that group II, fed FO, was characterized by higher ultimate $\mathrm{pH}$ (Table 1). The results for the TnT also showed lower proteolysis of meat from groups I, II, IV, and V because - as mentioned by Hopkins and Geesink (2009) - its degradation can be interpreted as an indicator of post mortem proteolysis. 
Electrophoretic profiles of muscle protein were affected by animal diet (Table 2). Meat from the lambs fed the diet containing fish oil (FO) (group II) was characterized by higher abundance of myosin LC1 and a lower content of $\alpha$-actinin compared to control meat (group I). LC1 myosin content was similar in group with $\mathrm{Ca}$ and inorganic Se (group III and $\mathrm{V}$ ) as in $\mathrm{FO}+\mathrm{CA}$ group (II) (Table 2). The addition of CA caused troponin $\mathrm{T}(\mathrm{Tn} \mathrm{T})$ to be less abundant in comparison to the samples from the control group (group I) and group II. However, the Se addition eliminated the influence of CA on TnT content. The samples from groups IV and V contained more TnT than these from group III (Table 2).

Se supplementation decreased the content of myosin $\mathrm{HC}$ and $150 \mathrm{kDa}$ polypeptides in meat samples in comparison to group III. Simultaneously, Se and CA addition caused the longissimus muscle to contain more $\alpha$-actinin when compared to group II. The addition of Se and CA eliminated the influence of FO on $\alpha$-actinin content. Furthermore, a significant increase in the $60 \mathrm{kDa}$ bands was observed in meat samples from groups IV and $\mathrm{V}$ in comparison to those from group III. Similarly, the $30 \mathrm{kDa}$ peptides were significantly more abundant in the samples from group $\mathrm{V}$ than from group III (Table 2). The observed results may also be due to the effect of combination of CA, FO and Se added to the diet.

The significant effects of feeding on myofibrillar protein proteolysis, sarcoplasmic protein profile and proteolytic enzymes activity have been studied by several authors (McDonagh et al., 1999; Santé-Lhoutellier et al., 2008; CostaLima et al., 2015; Maqsood et al., 2015). The results presented in Table 2 indicate a relation between antioxidant compounds of the diet and post mortem degradation of muscle proteins. Nevertheless, the results are difficult to make some generalization. It may be, however, concluded that CA promotes degradation of TnT, whereas the addition of SeVI to the feed increases degradation of myosin $\mathrm{HC}$ and content of $30 \mathrm{kDa}$ proteins. These results in relation to $\mathrm{TnT}$ are in accordance with works of Rowe et al. (2004), SantéLhoutellier et al. (2008) and Maqsood et al. (2015) and also confirm the protective and antioxidant effects of CA and Se in relation to proteolysis of myofibrillar proteins. Berardo et al. (2015) reported that protein oxidation reduces its proteolysis. Additionally, Shibata et al. (2009) demonstrated a significant effect of cattle feeding on troponin $\mathrm{T}$, troponin I and myosin HC content of semitendinosus muscle. Another study showed that feeding of animals could influence on the content of amino acids such as glutamine, aspartic acid, and taurine in muscle (Cornet and Bousset, 1999). Results presented in Table 4 also showed that the addition of FO, CA, and Se to animal diet influenced amino acid content in the longissimus muscle in the studied groups of lambs.

\subsection{Effect of lamb diets on drip loss protein profile}

Table 3 presents the protein profile of the drip loss from meat samples of the five analyzed groups. Among the identified proteins, the following ones were the most abundant: creatine kinase/phosphoglycerate kinase (CK/PGAK), $15.2 \%$; aldolase (ALD), 11.8\%; glyceraldehyde-3-phosphate dehydrogenase (GAPDH), $11.5 \%$; phosphoglucomutase (PGM), $11.0 \%$; pyruvate kinase/phosphoglucose isomerase (PK/PGI), 8.2\%; enolase (EN), 8.1\%; lactate dehydrogenase (LDH) $6.3 \%$; and phosphoglycerate mutase (PGAM), $6.3 \%$. The study of the available literature shows only results in relation to drip loss protein profile in other species than lambs. Nevertheless, the levels of AMP deaminase, CK/PGAK, PK/PGI, LDH, triosephosphate isomerase (TPI), GAPDH, and PGAM were similar to the ones obtained by Pérez et al. (2003) for pork. While the PGM and ALD were more abundant, EN was a little less abundant compared to the results reported by Pérez et al. (2003). In comparison to the study of Marino et al. (2014), the profile of TPI and LDH in our results was similar. The presence of other proteins proved to be similar in our study. For example, there was more PGM, ALD, and GAPDH, whereas there was less EN than in the work of Marino et al. (2014). However, a different content of PGAM was shown by these authors as affected by cattle breed. The study by these authors demonstrated that the percentages of the major sarcoplasmic protein bands extracted from the longissimus muscle were influenced by breed and ageing time. As was noted by Marino et al. (2014), these changes could be related to the chemical modification or other different mechanisms such as isoelectric precipitation due to $\mathrm{pH}$ decline or post mortem degradation.

The dietary inclusion of FO was observed to influence the content of PGM, PK/PGI, $55 \mathrm{kDa}$ peptides, PGAM, and TPI in drip loss. Meat of lambs from group II was characterized by a higher content of PGM and PK/PGI in drip loss compared to meat of control lambs. The opposite dependency was observed for $55 \mathrm{kDa}$ peptides, PGAM, and TPI. The addition of CA eliminated such an effect as samples from group III had a similar content of these proteins and peptides as the control ones (Table 3).

Drip loss from meat samples from groups IV and V contained significantly more 200 and $65 \mathrm{kDa}$ polypeptides and less CK/PGAK, ALD, and LDH when compared to group III. Moreover, drip loss from meat of animals fed with SeVI contained more $200 \mathrm{kDa}$ polyleptides and less ALD in comparison to animals fed with SeY. The influence of SeVI on the content of AMPDA has also been observed - this protein was more abundant in the samples from group $\mathrm{V}$ than in group IV. Additionally, SeVI supplementation caused a decrease in PK/PGI content in drip loss. However, a significantly higher content of PGM was measured in drip loss from meat of lambs fed with SeY (Table 3). Many studies have shown that sarcoplasmic proteins appeared as indicators of meat ageing and as biomarkers of some quality attributes, tenderness in particular (Di Luca et al., 2011; Sierra et al., 2012; Ouali et al., 2013; Bowker et al., 2014; Marino et al., 2014; Picard et al., 2015). These proteins include GAPDH, 
Table 3. Effect of different diets on protein profile in drip loss of the longissimus muscle of lambs after 7 days of ageing (\%).

\begin{tabular}{|c|c|c|c|c|c|}
\hline \multirow[t]{4}{*}{ Protein } & \multicolumn{5}{|c|}{ Group } \\
\hline & I & II & III & IV & V \\
\hline & \multicolumn{5}{|c|}{ Diet } \\
\hline & Control & $+1 \% \mathrm{FO}$ & $+1 \% \mathrm{FO}+0.1 \% \mathrm{CA}$ & $\begin{array}{l}+1 \% \mathrm{FO} \\
+0.1 \% \mathrm{CA} \\
+0.35 \mathrm{ppm} \mathrm{Se} \\
\text { as } \mathrm{SeY}\end{array}$ & $\begin{array}{l}+1 \% \mathrm{FO} \\
+0.1 \% \mathrm{CA} \\
+0.35 \mathrm{ppm} \mathrm{Se} \\
\text { as SeVI }\end{array}$ \\
\hline $200 \mathrm{kDa}$ & $\begin{array}{l}0.36^{\mathrm{a}} \\
\pm 0.29\end{array}$ & $\begin{array}{l}0.50^{\mathrm{a}} \\
\pm 0.39\end{array}$ & $\begin{array}{l}0.40^{\mathrm{a}} \\
\pm 0.18\end{array}$ & $\begin{array}{l}0.99^{\mathrm{b}} \\
\pm 0.54\end{array}$ & $\begin{array}{l}1.56^{\mathrm{c}} \\
\pm 0.48\end{array}$ \\
\hline $150 \mathrm{kDa}$ & $\begin{array}{l}0.90 \\
\pm .74\end{array}$ & $\begin{array}{l}0.82 \\
\pm 0.43\end{array}$ & $\begin{array}{l}0.47 \\
\pm 0.14\end{array}$ & $\begin{array}{l}0.87 \\
\pm 0.59\end{array}$ & $\begin{array}{l}1.00 \\
\pm 0.24\end{array}$ \\
\hline $\mathrm{PHb} / \mathrm{PHbK}$ & $\begin{array}{l}3.87 \\
\pm 1.01\end{array}$ & $\begin{array}{l}4.23 \\
\pm 0.80\end{array}$ & $\begin{array}{l}3.33 \\
\pm 0.35\end{array}$ & $\begin{array}{l}3.88 \\
\pm 0.87\end{array}$ & $\begin{array}{l}4.73 \\
\pm 0.71\end{array}$ \\
\hline AMPDA & $\begin{array}{l}1.81^{\mathrm{a}} \\
\pm 0.45\end{array}$ & $\begin{array}{l}1.87^{\mathrm{a}} \\
\pm 0.25\end{array}$ & $\begin{array}{l}1.39^{\mathrm{a}} \\
\pm 0.37\end{array}$ & $\begin{array}{l}1.80^{\mathrm{a}} \\
\pm 0.34\end{array}$ & $\begin{array}{l}3.16^{\mathrm{b}} \\
\pm 0.26\end{array}$ \\
\hline PGM & $\begin{array}{l}10.58^{a} \\
\pm 0.61\end{array}$ & $\begin{array}{l}11.31^{\mathrm{b}} \\
\pm 0.55\end{array}$ & $\begin{array}{l}10.52^{\mathrm{a}} \\
\pm 0.36\end{array}$ & $\begin{array}{l}12.06^{\mathrm{c}} \\
\pm 0.90\end{array}$ & $\begin{array}{l}10.51^{\mathrm{a}} \\
\pm 0.49\end{array}$ \\
\hline $65 \mathrm{kDa}$ & $\begin{array}{l}2.46^{\mathrm{a}} \\
\pm 0.11\end{array}$ & $\begin{array}{l}2.35^{\mathrm{a}} \\
\pm 0.13\end{array}$ & $\begin{array}{l}2.44^{\mathrm{a}} \\
\pm 0.19\end{array}$ & $\begin{array}{l}2.96^{\mathrm{b}} \\
\pm 0.37\end{array}$ & $\begin{array}{l}2.90^{\mathrm{b}} \\
\pm 0.19\end{array}$ \\
\hline PK/PGI & $\begin{array}{l}8.05^{\mathrm{ab}} \\
\pm 0.18\end{array}$ & $\begin{array}{l}8.57^{\mathrm{c}} \\
\pm 0.35\end{array}$ & $\begin{array}{l}8.07^{\mathrm{ab}} \\
\pm 0.56\end{array}$ & $\begin{array}{l}8.49^{b c} \\
\pm 0.38\end{array}$ & $\begin{array}{l}7.80^{\mathrm{a}} \\
\pm 0.35\end{array}$ \\
\hline $55 \mathrm{kDa}$ & $\begin{array}{l}1.79^{\mathrm{a}} \\
\pm 0.30\end{array}$ & $\begin{array}{l}1.10^{b} \\
\pm 0.63\end{array}$ & $\begin{array}{l}2.20^{\mathrm{a}} \\
\pm 0.17\end{array}$ & $\begin{array}{l}2.16^{\mathrm{a}} \\
\pm 0.65\end{array}$ & $\begin{array}{l}1.95^{\mathrm{a}} \\
\pm 0.33\end{array}$ \\
\hline $53 \mathrm{kDa}$ & $\begin{array}{l}1.13 \\
\pm 0.40\end{array}$ & $\begin{array}{l}1.53 \\
\pm 0.79\end{array}$ & $\begin{array}{l}0.58 \\
\pm 0.04\end{array}$ & $\begin{array}{l}0.70 \\
\pm 0.49\end{array}$ & $\begin{array}{l}0.94 \\
\pm 1.11\end{array}$ \\
\hline EN & $\begin{array}{l}7.86 \\
\pm 0.85\end{array}$ & $\begin{array}{l}8.40 \\
\pm 0.43\end{array}$ & $\begin{array}{l}8.01 \\
\pm 0.16\end{array}$ & $\begin{array}{l}8.20 \\
\pm 0.56\end{array}$ & $\begin{array}{l}8.09 \\
\pm 0.26\end{array}$ \\
\hline $45 \mathrm{kDa}$ & $\begin{array}{l}3.15 \\
\pm 1.06\end{array}$ & $\begin{array}{l}2.96 \\
\pm 0.35\end{array}$ & $\begin{array}{l}3.37 \\
\pm 0.19\end{array}$ & $\begin{array}{l}3.35 \\
\pm 0.35\end{array}$ & $\begin{array}{l}3.60 \\
\pm 0.54\end{array}$ \\
\hline CK/PGAK & $\begin{array}{l}15.62^{\mathrm{a}} \\
\pm 0.78\end{array}$ & $\begin{array}{l}15.85^{\mathrm{a}} \\
\pm 0.38\end{array}$ & $\begin{array}{l}16.32^{\mathrm{a}} \\
\pm 0.96\end{array}$ & $\begin{array}{l}14.25^{\mathrm{b}} \\
\pm 0.56\end{array}$ & $\begin{array}{l}14.12^{\mathrm{b}} \\
\pm 0.57\end{array}$ \\
\hline ALD & $\begin{array}{l}12.54^{\mathrm{c}} \\
\pm 0.70\end{array}$ & $\begin{array}{l}12.42^{\mathrm{c}} \\
\pm 0.63\end{array}$ & $\begin{array}{l}12.52^{\mathrm{c}} \\
\pm 0.15\end{array}$ & $\begin{array}{l}11.14^{\mathrm{b}} \\
\pm 0.41\end{array}$ & $\begin{array}{l}10.43^{\mathrm{a}} \\
\pm 0.32\end{array}$ \\
\hline GAPDH & $\begin{array}{l}11.54 \\
\pm 0.75\end{array}$ & $\begin{array}{l}11.07 \\
\pm 0.69\end{array}$ & $\begin{array}{l}11.49 \\
\pm 0.53\end{array}$ & $\begin{array}{l}11.44 \\
\pm 0.86\end{array}$ & $\begin{array}{l}11.74 \\
\pm 1.11\end{array}$ \\
\hline LDH & $\begin{array}{l}6.52^{\mathrm{a}} \\
\pm 0.48\end{array}$ & $\begin{array}{l}6.62^{\mathrm{a}} \\
\pm 0.42\end{array}$ & $\begin{array}{l}6.80^{\mathrm{a}} \\
\pm 0.26\end{array}$ & $\begin{array}{l}5.84^{b} \\
\pm 0.28\end{array}$ & $\begin{array}{l}5.57^{\mathrm{b}} \\
\pm 0.21\end{array}$ \\
\hline PGAM & $\begin{array}{l}6.56^{\mathrm{a}} \\
\pm 0.46\end{array}$ & $\begin{array}{l}5.70^{\mathrm{b}} \\
\pm 1.06\end{array}$ & $\begin{array}{l}6.80^{\mathrm{a}} \\
\pm 0.33\end{array}$ & $\begin{array}{l}6.21^{\mathrm{ab}} \\
\pm 0.28\end{array}$ & $\begin{array}{l}6.19^{\mathrm{ab}} \\
\pm 0.48\end{array}$ \\
\hline TPI & $\begin{array}{l}3.66^{\mathrm{ac}} \\
\pm 0.21\end{array}$ & $\begin{array}{l}3.29^{c} \\
\pm 0.87\end{array}$ & $\begin{array}{l}3.82^{\mathrm{ab}} \\
\pm 0.08\end{array}$ & $\begin{array}{l}4.23^{b} \\
\pm 0.16\end{array}$ & $\begin{array}{l}4.01^{\mathrm{ab}} \\
\pm 0.22\end{array}$ \\
\hline $23 \mathrm{kDa}$ & $\begin{array}{l}1.57 \\
\pm 0.08\end{array}$ & $\begin{array}{l}1.40 \\
\pm 0.13\end{array}$ & $\begin{array}{l}1.45 \\
\pm 0.20\end{array}$ & $\begin{array}{l}1.40 \\
\pm 0.32\end{array}$ & $\begin{array}{l}1.67 \\
\pm 0.23\end{array}$ \\
\hline
\end{tabular}

a, b, c - means with different superscripts in the same row differ significantly at $P_{\alpha} \leq 0.05$. FO - fish oil; CA - carnosic acid; SeY - the organic chemical form of selenium; SeVI - selenate; PHb/PHbK - phosphorylase b/phosphorylase b kinase; PFK - phosphofructokinase; AMPDA - AMP deaminase; PGM - phosphoglucomutase; PK/PGI - pyruvate kinase/phosphoglucose isomerase; EN - enolase; CK/PGAK - creatine kinase/phosphoglycerate kinase; ALD - aldolase; GAPDH - glyceraldehyde-3-phosphate dehydrogenase; LDH - lactate dehydrogenase; PGAM phosphoglycerate mutase; TPI - triosephosphate isomerase. 
Table 4. Effect of different diets on the content ( $\mathrm{g} / 100 \mathrm{~g}$ fresh muscle tissues) of amino acids (AAs) in the longissimus muscle of lambs.

\begin{tabular}{|c|c|c|c|c|c|}
\hline \multirow[t]{4}{*}{ Amino acids } & \multicolumn{5}{|c|}{ Group } \\
\hline & I & II & III & IV & $\mathrm{V}$ \\
\hline & \multicolumn{5}{|c|}{ Diet } \\
\hline & Control & $+1 \% \mathrm{FO}$ & $+1 \% \mathrm{FO}+0.1 \% \mathrm{CA}$ & $\begin{array}{l}+1 \% \mathrm{FO} \\
+0.1 \% \mathrm{CA} \\
+0.35 \mathrm{ppm} \mathrm{Se} \\
\text { as } \mathrm{SeY}\end{array}$ & $\begin{array}{l}+1 \% \mathrm{FO} \\
+0.1 \% \mathrm{CA} \\
+0.35 \mathrm{ppm} \mathrm{Se} \\
\text { as SeVI }\end{array}$ \\
\hline Aspartic acid & $1.74^{\mathrm{b}}$ & $1.54^{\mathrm{a}}$ & $1.56^{\mathrm{a}}$ & $1.62^{\mathrm{ab}}$ & $1.69^{\mathrm{ab}}$ \\
\hline Glutamic acid & $2.92^{b}$ & $2.62^{\mathrm{a}}$ & $2.64^{\mathrm{a}}$ & $2.62^{\mathrm{a}}$ & $2.75^{\mathrm{ab}}$ \\
\hline Asparagine & 0.15 & 0.14 & 0.12 & 0.13 & 0.14 \\
\hline Histidine & $1.54^{\mathrm{b}}$ & $1.41^{\mathrm{a}}$ & $1.33^{\mathrm{a}}$ & $1.29^{\mathrm{a}}$ & $1.34^{\mathrm{a}}$ \\
\hline Serine & $0.77^{\mathrm{b}}$ & $0.68^{\mathrm{a}}$ & $0.66^{\mathrm{a}}$ & $0.71^{\mathrm{ab}}$ & $0.67^{\mathrm{a}}$ \\
\hline Arginine & $2.02^{\mathrm{c}}$ & $1.85^{\mathrm{c}}$ & $1.72^{\mathrm{cb}}$ & $1.58^{\mathrm{ab}}$ & $1.63^{\mathrm{ab}}$ \\
\hline Glycine & $0.46^{\mathrm{b}}$ & $0.41^{\mathrm{a}}$ & $0.40^{\mathrm{a}}$ & $0.42^{\mathrm{ab}}$ & $0.44^{\mathrm{ab}}$ \\
\hline Threonine & $0.46^{\mathrm{b}}$ & $0.40^{\mathrm{a}}$ & $0.41^{\mathrm{a}}$ & $0.43^{\mathrm{ab}}$ & $0.45^{\mathrm{ab}}$ \\
\hline Tyrosine & $2.11^{\mathrm{ab}}$ & $1.98^{\mathrm{ab}}$ & $1.83^{\mathrm{a}}$ & $2.07^{\mathrm{ab}}$ & $2.23^{\mathrm{b}}$ \\
\hline Alanine & $0.06^{\mathrm{a}}$ & $0.04^{\mathrm{a}}$ & $0.04^{\mathrm{a}}$ & $0.07^{\mathrm{a}}$ & $0.12^{\mathrm{b}}$ \\
\hline Methionine & $0.19^{\mathrm{a}}$ & $0.20^{\mathrm{a}}$ & $0.22^{\mathrm{a}}$ & $0.24^{\mathrm{ab}}$ & $0.28^{b}$ \\
\hline Valine & $0.46^{\mathrm{b}}$ & $0.46^{\mathrm{b}}$ & $0.47^{\mathrm{b}}$ & $0.42^{\mathrm{ab}}$ & $0.36^{\mathrm{a}}$ \\
\hline Phenylalanine & $0.55^{\mathrm{bc}}$ & $0.48^{\mathrm{a}}$ & $0.52^{\mathrm{ab}}$ & $0.59^{\mathrm{bc}}$ & $0.60^{\mathrm{c}}$ \\
\hline iso-Leucine & $0.63^{\mathrm{b}}$ & $0.55^{\mathrm{a}}$ & $0.56^{\mathrm{ab}}$ & $0.61^{\mathrm{b}}$ & $0.62^{b}$ \\
\hline Leucine & $1.50^{\mathrm{b}}$ & $1.36^{\mathrm{a}}$ & $1.32^{\mathrm{a}}$ & $1.32^{\mathrm{a}}$ & $1.36^{\mathrm{a}}$ \\
\hline Cysteine & $0.26^{\mathrm{b}}$ & $0.25^{\mathrm{b}}$ & $0.23^{\mathrm{ab}}$ & $0.19^{\mathrm{a}}$ & $0.19^{\mathrm{a}}$ \\
\hline homo-Cystine & 0.006 & 0.005 & 0.006 & 0.006 & 0.006 \\
\hline Lysine & $1.48^{\mathrm{c}}$ & $1.34^{\mathrm{b}}$ & $1.27^{\mathrm{ab}}$ & $1.11^{\mathrm{a}}$ & $1.21^{\mathrm{ab}}$ \\
\hline$\sum \mathrm{AAs}$ & $17.32^{\mathrm{b}}$ & $15.72^{\mathrm{a}}$ & $15.31^{\mathrm{a}}$ & $15.43^{\mathrm{a}}$ & $16.08^{\mathrm{ab}}$ \\
\hline$\sum$ IAAs & $5.27^{\mathrm{b}}$ & $4.80^{\mathrm{a}}$ & $4.76^{\mathrm{a}}$ & $4.72^{\mathrm{a}}$ & $4.87^{\mathrm{ab}}$ \\
\hline$\sum \mathrm{DAAs}$ & $12.04^{\mathrm{b}}$ & $10.92^{\mathrm{a}}$ & $10.54^{\mathrm{a}}$ & $10.70^{\mathrm{a}}$ & $11.20^{\mathrm{ab}}$ \\
\hline$\sum$ IAAs / $\sum$ DAAs & $0.438^{\mathrm{a}}$ & $0.440^{\mathrm{ab}}$ & $0.451^{\mathrm{b}}$ & $0.441^{\mathrm{ab}}$ & $0.435^{\mathrm{a}}$ \\
\hline$\sum \mathrm{IAAs} / \sum \mathrm{AAs}$ & $0.305^{\mathrm{a}}$ & $0.305^{\mathrm{a}}$ & $0.311^{\mathrm{b}}$ & $0.306^{\mathrm{a}}$ & $0.303^{\mathrm{a}}$ \\
\hline Met / $\sum$ AAs & $0.0108^{\mathrm{a}}$ & $0.0130^{\mathrm{a}}$ & $0.0143^{\mathrm{a}}$ & $0.0158^{b}$ & $0.0171^{b}$ \\
\hline
\end{tabular}

a, b, c - means with different superscripts in the same row differ significantly at $P \alpha \leq 0.05$. FO - fish oil; CA - carnosic acid; SeY - the organic chemical form of selenium; SeVI - selenite; $\sum$ AAs - the sum of amino acids content; $\sum$ IAAs - the sum of indispensable amino acids content; $\sum$ DAAs - the sum of dispensable amino acids content; Met / $\sum$ AAs - the ratio of methionine (Met) to $\sum$ AAs content.

EN, LDH, PGM, TPI, and phosphorylase b/phosphorylase b kinase (PHb/PHbK). Di Luca et al. (2013b) stated that muscle exudate could be a good source of these proteins because it provides valuable information about the pathways and processes underlying the post mortem ageing period as well as highlighting its post mortem modifications. Some studies have also shown that sarcoplasmic protein profile in drip loss is also determined by the feeding of animals (Shibata et al., 2009; Costa-Lima et al., 2015). These results demonstrated effects of feeding factors on the abundance of glycolytic enzymes and indicated that they could potentially affect changes occurring in muscle tissue after slaughter and, consequently, the quality of meat. In our study, we also observed a feeding effect on contents of the following sarcoplasmic proteins: AMPDA, PGM, PK/PGI, CK/PGAK, ALD, LDH, PGAM, and TPI (Table 3).
According to the results presented in Table 3, the groups fed diets with Se (IV and V) were characterized by lower contents of CK/PGAK, ALD, and LDH in comparison to group III. These results are in part consistent with the study of El-Neweehy et al. (2000), who showed that selenium contributed to a significant decrease in serum muscle-specific enzymes such as LDH. Bostedt (1976) reported on a significant increase in muscle CPK (creatine phosphokinase) in lambs of an endemic flock although they were clinically healthy and returned to normal levels within 1 week after single injection of selenium. Additionally, a research by Morán et al. (2012b) showed no effect of CA $\left(0.6\right.$ and $\left.1.2 \mathrm{~g} \mathrm{~kg}^{-1}\right)$ in the diet of lambs on the serum levels of glucose, CPK, and LDH. However, it demonstrated a lower content of creatine phosphokinase in the antioxidant groups (fed with carnosic acid and vitamin $\mathrm{E})$. 


\subsection{Correlation between sarcoplasmic proteins and some meat quality traits}

The statistical analysis showed intermediate and significant negative correlations between $\mathrm{pH}_{48}$ and TPI and PGAM ( $r=-0.40 ; P_{\alpha} \leq 0.05$ for both enzymes). The correlation between sarcoplasmic proteins and some meat quality traits as color stability or water-holding capacity has been studied by many authors (Sayd et al., 2006; Di Luca et al., 2013b; Canto et al., 2015; Gao et al., 2016; Nair et al., 2016). Di Luca et al. (2013b) demonstrated lower abundance of TPI in the samples with high drip loss. This enzyme plays an important role in glycolysis and catalyzes the interconversion of dihydroxyacetone phosphate and glyceraldehyde 3-phosphate (Di Luca et al., 2013a). However, PGAM catalyzes the internal transfer of a phosphate group, which results in the conversion of 3-phosphoglycerate to 2-phosphoglycerate (Scheffler and Gerrard, 2007). The lower level of these two enzymes could be related to insufficient glycolysis and higher ultimate $\mathrm{pH}$ in group II (Table 1), in other groups, characterized by higher concentrations of these enzymes (especially PGAM), the $\mathrm{pH}_{48}$ was significantly lower. Similarly, $\mathrm{pH}_{48}$ was related to EN, but positively; the calculated correlation was $r=$ $0.40\left(P_{\alpha} \leq 0.05\right)$. EN catalyzes the penultimate reaction of the glycolysis pathway: dehydration of 2-phosphoglycerate to phosphoenolpyruvate. Sayd et al. (2006), Nair et al. (2016) and Gao et al. (2016) indicated that EN was related rather to color parameters of meat.

The obtained results showed also a significant correlation between color parameter $a^{*}$ and $\operatorname{ALD}\left(r=0.50 ; P_{\alpha} \leq 0.05\right)$ and LDH $\left(r=0.40 ; P_{\alpha} \leq 0.05\right)$. ALD is involved in the aldol cleavage reaction. The substrate for ALD is fructose1,6-bis-phosphate, which is cleaved to the glyceraldehyde 3phosphate and dihydroxyacetone phosphate. This is the final reaction of the first stage of glycogenolysis. Whereas LDH catalyzes the last step of the glycolytic pathway, i.e., the conversion of pyruvate to lactate. In a study conducted by Przybylski et al. (2016), a significant correlation $(r=0.58)$ was observed between ALD and color parameters. However, Gao et al. (2016) demonstrated a significant correlation between redness ( $a^{*}$ value) of sheep cardiac muscle and CK. Żelechowska et al. (2012) and Ramirez et al. (2004) also reported on significant correlations between ALD and the $b^{*}$ color parameter in pork and rabbit meat, respectively.

\subsection{Effect of lamb diets on amino acid profile in Longissimus muscle}

The results summarized in Table 4 show that the diets fed to groups II to $\mathrm{V}$ showed at least a tendency to decrease the sum of all amino acids ( $\sum$ AAs) as well as of indispensable amino acids ( $\sum$ IAAs) and dispensable amino acids ( $\sum$ DAAs) in the muscle as compared to the control diet. In fact, the lower $\sum$ AAs, including $\sum$ IAAs and $\sum$ DAAs, in the muscle of lambs fed the diets containing FO, irre- spective of the addition of CA, SeY or SeVI (the II-V diets), can be attributed to the diminished ruminal microbial protein synthesis (i.e., bacterial growth in the rumen) or to stimulated ruminal bacterial degradation of a larger portion of amino acids originating from dietary protein in the rumen, especially when the diet was supplemented with FO and CA (the III diet). Really, Maia et al. (2007) showed that the fish oil long-chain polyunsaturated fatty acids (like eicosapentaenoic acid (EPA; C20:5n-3) and docosahexaenoic acid (DHA; C22:6n-3)) inhibited the growth of ruminal bacteria; toxicity to growth was ranked EPA $>$ DHA $>$ C18:3n-3 $(\alpha$ LNA) $>$ C18:2n-6 (LA). Similarly, Buccioni et al. (2012) showed that dietary FO (especially long-chain polyunsaturated fatty acids) revealed a toxic effect on ruminal microorganisms. Moreover, according to Dimov et al. (2012), the diet composition may affect the capacity of the bacterial degradation of amino acids originating from dietary proteins as well as bacterial protein synthesis in the rumen.

Moreover, SeVI (the inorganic form of Se) added to the diet (the $\mathrm{V}$ diet) tended to increase $(P=0.07)$ the total content of amino acids ( $\left.\sum \mathrm{AAs}\right)$ in the muscle in comparison with $\mathrm{SeY}$ (the organic form of Se) added to the diet (the IV diet). In fact, the higher content of amino acids in the longissimus muscle results in a lower content of fatty acids in the longissimus muscle (Jaworska et al., 2016). In fact, numerous investigations support the concept that the Se prooxidative effect of diets containing extra inorganic Se compounds (like SeVI or selenite) is due to the catalysis of hydrosulfide oxidation that results in decreasing the biosynthesis yield of lipogenic enzymes (e.g., acetyl-CoA carboxylase and fatty acid synthase) in tissues of animals (NavarroAlarcon and Cabrera-Vique, 2008). In this study the lower content of $\sum$ AAs in the muscle of lambs fed the III diet compared with the control group (the I diet) was observed and also lower content of FAs, including saturated FAs, in the longissimus muscle was observed in work of Jaworska et al. (2016). Interestingly, this diet most efficiently increased the ratio of indispensable amino acids ( $\sum$ IAAs) to $\sum$ AAs ( $\sum$ IAAs / $\sum$ AAs) content in the muscle. Indeed, the nutritive quality of the longissimus muscle of lambs is related primarily to such indispensable amino acids like histidine, methionine, lysine, and phenylalanine (Brzostowski et al., 2008). Moreover, the current studies and our recent research (Jaworska et al., 2016) showed that CA added to the diet enriched in FO (the III diet) most efficiently increased the accumulation of unsaturated fatty acids as well as improved the n-3PUFA to n-6PUFA (n-3PUFA / n-6PUFA) and $\sum$ IAA to $\sum$ DAA ( $\sum$ IAA / $\sum$ DAA) ratios in the longissimus muscle of lambs. Moreover, our recent research showed that dietary $\mathrm{RO}, \mathrm{FO}$, and CA, regardless of the presence of SeVI, improved sensory texture quality of the longissimus muscle of lambs (Jaworska et al., 2016). In fact, the inability of many farm animals and humans to synthesize certain AAs has long triggered tremendous interest in increasing contributions of IAAs (especially methionine, lysine, and tryptophan) in di- 
ets (Ufaz and Galili, 2008). Interestingly, the simultaneous addition of FO, CA, and SeVI to diet with RO (the V diet) stimulated the incorporation of methionine in the muscle as compared with the control, II, and III diets. Moreover, SeVI added to the diet with FO, RO, and CA (group V) more efficiently increased the $\sum$ AAs, including tyrosine, alanine, methionine, and phenylalanine, in the muscle than the III diet. Considering the above results, we argued that especially the inorganic chemical form of dietary Se (i.e., SeVI) and particularly SeVI metabolites (like metabolites of selenides or seleno-cysteine) reduced bacterial degradation of these amino acids in the rumen and/or stimulated the biosynthesis of proteins rich in these amino acids in the longissimus muscle of lambs. Indeed, numerous studies have shown that dietary Se compounds affected ruminal microorganism profile and activity of microbiota; hence, it might be concluded that dietary Se compounds affect volatile fatty acid production and yield of microbial fermentation in the rumen (Kim et al., 1997; Del Razo-Rodrigues et al., 2013).

Considering the above results, we argued that dietary SeY and particularly SeVI metabolites (like metabolites of selenides or seleno-cysteine) reduced bacterial degradation of these amino acids in the rumen and/or stimulated the biosynthesis of proteins rich in these amino acids in the longissimus muscle of lambs.

Interestingly, the addition of $\mathrm{Se}$ (as $\mathrm{SeY}$ or $\mathrm{SeVI}$ ) to the diet with FO, RO, and CA most effectively increased the content of methionine, as well as the ratio of methionine content to $\sum$ AAs (Met / $\sum$ AAs) in this muscle (Table 4). Contrary to the $\mathrm{V}$ diet, the IV diet less efficiently $(P=0.08)$ stimulated the accumulation of methionine in the muscle because only a part of dietary SeY (rich in Se-Met) is metabolized into metabolites of selenides or seleno-cysteine in the body system of animals fed a diet with the adequate concentration of Se (Navarro-Alarcon et al., 2008). These findings are consistent with the effects of diets enriched in $\mathrm{SeY}$ or SeVI (the $\mathrm{IV}$ and $\mathrm{V}$ diets) on the content of cysteine in the muscle of the examined lambs; the conversion of methionine to cysteine is an irreversible process in the animal body (Navarro-Alarcon et al., 2008). Consequently, the IV and V diets more effectively decreased the content of cysteine in the muscle than the III $\operatorname{diet}(P<0.1$; the tendency) and especially the control and II diets $(P \leq 0.05)$.

Interestingly, all supplemented diets (the II-V diets), especially the diet with SeY (the IV diet), decreased $(P \leq 0.05)$ the content of lysine in the muscle compared with the control diets. Furthermore, the IV diet reduced the content of lysine in the muscle as compared with the muscle of lambs fed the II diet. Considering the above, we argued that the II$\mathrm{V}$ diets including FO (rich in long-chain PUFA), irrespective of the presence of CA, SeVI, and especially SeY, decreased the biosynthesis yield of proteins rich in lysine in the lambs' muscle.

\section{Conclusions}

In conclusion, the results show that supplementation of lamb diet with FO, CA, and Se significantly affects ultimate $\mathrm{pH}$ and color parameters, the content of amino acids in the muscle, and the protein profile of myofibrillar and sarcoplasmic proteins. Meat from lambs fed diets with FO addition was characterized by higher $\mathrm{pH}_{48}$ and less intense lightness, redness, and yellowness of meat. The significant differences between groups were noted as for the contents of myosin $\mathrm{HC}$ and $\mathrm{LC} 1,150 \mathrm{kDa} ; \alpha$-actinin, $60 \mathrm{kDa}$; and TnT, $30 \mathrm{kDa}$ protein. However, it can be concluded that the addition of only FO to lamb diet with RO resulted in a lower content of $30 \mathrm{kDa}$ protein which is a predictor of proteolysis and it is compatible with higher ultimate $\mathrm{pH}$. Considering the protein profile in drip loss, results showed effects of feeding FA, $\mathrm{CA}$, and $\mathrm{Se}$ on the abundance of the sarcoplasmic proteins AMPDA, PGM, PK/PGI, CK/PGAK, ALD, LDH, PGAM, and TPI, and that it could potentially affect the changes occurring in muscle tissue after slaughter and consequently the quality of meat. The lower content of TPI and PGAM could be related to insufficient glycolysis and higher ultimate $\mathrm{pH}$ in the group with dietary inclusion of FO. The results also showed that $\mathrm{Se}$ addition resulted in lowering CK/PGAK, ALD, and LDH levels. All experimental diets decreased the sum of all assayed amino acids ( $\left.\sum A A s\right)$, indispensable amino acids ( $\sum$ IAAs) and dispensable amino acids ( $\sum$ DAAs) in the muscle. The highest $\sum$ IAAs to $\sum$ DAAs and $\sum$ IAAs to $\sum$ AAs ratios were found in the muscle of lambs fed the CA diet. All experimental diets, especially the CASeVI diet, increased the abundance of methionine in the muscle.

Data availability. The original data are available upon request from the corresponding authors.

Author contributions. Marian Czauderna and Wiesław Przybylski designed the study. Marian Czauderna and Krzysztof Wereszka performed the experiments. Marian Czauderna and Wiesław Przybylski collected the samples. Wiesław Przybylski, Marian Czauderna, Elżbieta Żelechowska, Katarzyna Kalicka, and Krzysztof Wereszka performed the chemical analyses. Wiesław Przybylski analyzed the data and did the statistical analysis. Wiesław Przybylski, Marian Czauderna, Elzbieta Żelechowska, and Danuta Jaworska edited and reviewed the paper.

Competing interests. The authors declare that they have no conflict of interest. 
Acknowledgements. This study was in part supported by the National Science Centre (NCN, grant no. 2013/09/B/NZ9/00291) and in second part through statutory activity.

Edited by: S. Maak

Reviewed by: two anonymous referees

\section{References}

AOAC: Nitrogen in meat, Kjeldahl method, Official Method, 928.08, 1974.

Aouadi, D., Luciano, G., Vasta, V., Nasri, S., Brogna, D. M. R., Abidi, S., Priolo, A., and Salem, H. B.: The antioxidant status and oxidative stability of muscle from lambs receiving oral administration of Artemisia herba alba and Rosmarinus officinalis essential oils, Meat Sci., 97, 237-243, 2014.

Bañón, S., Méndez, L., and Almela, E.: Effects of dietary rosemary extract on lamb spoilage under retail display conditions, Meat Sci., 90, 579-583, 2012.

Bee, G., Anderson, A. L., Lonergan, S. M., and Huff-Lonergan, E.: Rate and extent of $\mathrm{pH}$ decline affect proteolysis of cytoskeletal proteins and water-holding capacity in pork, Meat Sci., 76, 359365, 2007.

Berardo, A., Claeys, E., Vossen, E., Leroy, F., and De Smet, S.: Protein oxidation affects proteolysis in a meat model system, Meat Sci., 106, 78-84, 2015.

Bollag, D. M. and Edestein, S. J.: Protein Methods, New York, Wiley, Liss, Inc., 1999.

Bostedt, H.: Serum enzymatische Untersuchungen bei Lämmern im Alter 10-30 Tage gleicheitig in Beitrag zur prophylaxe der enzootischen Muskeldystrophie, Berl Munch. Tieraztl. Wschrt Publication, 1976.

Bowker, B. C., Eastridge, J. S., and Solomon, M. B.: Measurement of muscle exudate protein composition as an indicator of beef tenderness, J. Food Sci., 79, 1292-1297, 2014.

Brzostowski, H., Niżnikowski, R., and Tański, Z.: Quality of goat meat from purebred French Alpine kids and Boer crossbreeds, Arch. Tierz., Dummerstorf, 51, 381-388, 2008.

Buccioni, A., Decandia, M., Minieri, S., Molle, G., and Cabiddu, A.: Lipid metabolism in the rumen. New insights on the lipolysis and biohydrogenation with an emphasis on the role of endogenous plant factors, Anim. Feed Sci. Technol., 174, 1-25, 2012.

Canto, A. C. V. C. S., Suman, S. P., Nair, M. N., Li, S., Rentfrow, G., Beach, C. M., Silva, T. J. P., Wheeler, T. L., Shackelford, S. D., Grayson, A., McKeith, R. O., and King, D. A.: Differential abundance of sarcoplasmic proteome explains animal effect on beef Longissimus lumborum color stability, Meat Sci., 102, 9098, 2015.

Caputi-Jambrenghi, A., Colonna, M. A., Giannico, F., Favia, R., Minuti, F., Scafizzari, M., and Vonghia, G.: Dietary supplementation of garlic and rosemary: Effects on colour stability and lipid oxidation in lamb meat, Ital. J. Anim. Sci., 4, 366-368, 2005.

Cobellis, G., Yu, Z., Forte, C., Acuti, G., and Trabalza-Marinucci, M.: Dietary supplementation of Rosmarinus officinalis L. leaves in sheep affects abundance of rumen methanogens and other microbial populations, J. Anim. Sci. Biotechnol., 7, doi:10.1186/s40104-016-0086-8, 2016.
Cornet, M. and Bousset, J.: Free amino acid and dipeptides in porcine muscles: Differences between red and white muscle, Meat Sci., 51, 215-219, 1999.

Costa-Lima, B. R. C., Suman, S. P., Li, S., Beach, C. M., Silva, T. J. P., Silveira, E. T. F., Bohrer, B. M., and Boler, D. D.: Dietary ractopamine influences sarcoplasmic proteome profile of pork Longissimus thoracis, Meat Sci., 103, 7-12, 2015.

Czauderna, M., Kowalczyk, J., Niedźwiedzka, K. M., and Wasowska, I.: Determination of free- and protein primary amino acids in biological materials by high-performance liquid chromatography and photodiode array detection, J. Anim. Feed Sci., 11, 143-167, 2002.

Czauderna, M., Kowalczyk, J., Niedźwiedzka, K. M., Leng, L., and Cobanova, K.: Dietary selenized yeast and CLA isomer mixture affect fatty- and amino acid concentrations in the femoral muscles and liver of rats, J. Anim. Feed Sci., 18, 348-361, 2009.

Del Razo-Rodriguez, O. E., Ramirez-Bribiesca, J. E., LopezArellano, R., Revilla-Vazquez, A. L., Gonzalez-Munoz, S. S., Cobos-Peralta, M. A., Hernandez-Calva, L. M., and McDowell, L. R.: Effects of dietary level of selenium and grain on digestive metabolism in lambs, Czech J. Anim. Sci., 58, 253-261, 2013.

Del Razo-Rodriguez, O. E., Ramirez-Bribiesca, J. E., LopezArellano, R., Revilla-Vazquez, A. L., Gonzalez-Munoz, S. S., Cobos-Peralta, M. A., Hernandez-Calva, L. M., and McDowell, L. R.: Effects of dietary level of selenium and grain on digestive metabolism in lambs, Czech. J. Anim. Sci., 58, 253-261, 2013.

Di Luca, A., Elia, G., Hamill, R., and Mullen, A. M.: 2D DIGE proteomic analysis of early post mortem muscle exudate highlights the importance of the stress response for improved water-holding capacity of fresh pork meat, Proteomics, 13, 1528-1544, $2013 \mathrm{a}$.

Di Luca, A., Elia, G., Mullen, A. M., and Hamill, R. M.: Monitoring post mortem changes in porcine muscle through 2-D DIGE proteome analysis of Longissimus muscle exudate, Proteome Sci., 11, 9-12, 2013b.

Di Luca, A., Mullen, A. M., Elia, G., Davey, G., and Hamill, R. M.: Centrifugal drip is an accessible source for protein indicators of pork ageing and water-holding capacity, Meat Sci., 88, 261-270, 2011.

Dimov, K., Kalev, R., and Penchev, P.: Effect of finishing diet with excluded silage on amino-acid, fatty-acid, and mineral composition of meat ( $m$. longisimus dorsi) in calves, Bul. J. Agr. Sci., 18, 288-295, 2012.

El-Neweehy, T. K., Al-Qarawi, A. A., and Abdel-Rahman, H. A.: Some studies on stiff lamb disease in Qassim region in Saudi Arabia. 1: Enzymatic profile in free, subclinically and clinically affected lambs both before and after treatment with vitamin $\mathrm{E}$ and selenium preparation, Small Rumin. Res., 35, 219-223, 2000.

Gao, X., Wu, W., Ma, Ch., Li, X., and Dai, R. Postmortem changes in sarcoplasmic proteins associated with color stability in lamb muscle analyzed by proteomics, Eur. Food Res. Technol., 242, 527-535, 2016.

Gornall, A. G., Bardawill, C. J., and David, M. M.: Determination of serum proteins by means of the biuret reaction, J. Biol. Chem., 177, 751-766, 1949.

Hopkins, D. L. and Geesink, G. H.: Protein degradation postmortem and tenderization, in: Applied Muscle Biology and Meat Science, edited by: Min, D. and McCormick, R. J., CRC Press Taylor \& Francis Group, USA, 149-173, 2009. 
Hopkins, D. L. and Thompson, J. M.: The relationship between post-mortem calcium concentration or $\mathrm{pH}$ and indicators of proteolysis in ovine muscle, Meat Sci., 61, 411-414, 2002.

Huff-Lonergan, E. and Lonergan, S. M.: Mechanisms of waterholding capacity of meat: The role of postmortem biochemical and structural changes, Meat Sci., 71, 194-204, 2005.

Huff-Lonergan, E. and Lonergan, S. M.: New frontiers in understanding drip loss in pork: recent insights on the role of postmortem muscle biochemistry, J. Anim. Breed Genet., 124 (Suppl.1), 19-26, 2007.

Huff-Lonergan, E., Zhang, W., and Lonergan, S. M.: Biochemistry of postmortem muscle - Lessons on mechanisms of meat tenderization, Meat Sci., 86, 184-195, 2010.

Jaworska, D., Przybylski, W., Czauderna, M., Rozbicka-Wieczorek, A. J., and Półtorak, A.: Meat quality of lambs feed diets enriched with fish and rapeseed oils, carnosic acid and seleno-compounds, Meat Sci., 119, 185-192, 2016.

Jordan, M. J., Lax, V., Rota, M. C., Loran, S., and Sotomayor, J. A.: Effect of the phenological stage on the chemical composition, and antimicrobial and antioxidant properties of Rosmarinus officinalis L essential oil and its polyphenolic extract, Ind. Crop. Prod., 48, 144-152, 2013.

Kim, J., Van Soest, P. J., and Combs Jr., G. F.: Studies on the effects of selenium on rumen microbial fermentation in vitro, Biol. Trace Elem. Res., 56, 203-213, 1997.

Kišidayová, S., Mihaliková, K., Siroka, P., Čobanová, K., and Váradyová, Z.: Effects of inorganic and organic selenium on the fatty acid composition of rumen contents of sheep and the rumen bacteria and ciliated protozoa, Anim. Feed Sci. Tech., 193, 51-57, 2014.

Kołczak, T., Pospiech, E., Palka, K., and Łącki, J.: Changes of myofibrillar and centrifugal drip proteins and shear force of psoas major and minor and semitendinosus muscles from calves, heifers and cows during post-mortem ageing, Meat Sci., 64, 6975, 2003.

Li, J. G., Zhou, J. C., Zhao, H., Lei, X. G., Xia, X. J., Gao, G., and Wang, K. N.: Enhanced water-holding capacity of meat was associated with increased Sepwl gene expression in pigs fed selenium-enriched yeast, Meat Sci., 87, 95-100, 2011.

Luciano, G., Monahan, F. J., Vasta, V., Biondi, L., Lanza, M., and Priolo, A.: Dietary tannins improve lamb meat colour stability, Meat Sci., 81, 120-125, 2009a.

Luciano, G., Monahan, F. J., Vasta, V., Pennisi, P., Bella, M., and Priolo, A.: Lipid and colour stability of meat from lambs fed fresh herbage or concentrate, Meat Sci., 82, 193-199, $2009 \mathrm{~b}$.

Maia, M. R. G., Chaudhary, L. C., Figueres, L., and Wallace, R. J.: Metabolism of polyunsaturated fatty acids and their toxicity to the microflora of the rumen, Antonie van Leeuwenhoek, 91, 303-314, 2007.

Maqsood, S., Abushelaibi, A., Manheem, K., and Al Rashedi, A.: Lipid oxidation, protein degradation, microbial and sensorial quality of camel meat as influenced by phenolic compounds, LWT - Food Sci. Technol., 63, 953-959, 2015.

Marino, R., Albenzio, M., Della Malva, A., Caroprese, M., Santillo, A., and Sevi, A.: Changes in meat quality traits and sarcoplasmic proteins during aging in three different cattle breeds, Meat Sci., 98, 178-186, 2014.

McDonagh, M. B., Fernandez, C., and Oddy, V. H.: Hind-limb protein metabolism and calpain system activity influence post- mortem change in meat quality in lamb, Meat Sci., 52, 9-18, 1999.

Miltko, R., Rozbicka-Wieczorek, J. A., Więsyk, E., and Czauderna, M.: The influence of different chemical forms of selenium added to the diet including carnosic acid, fish oil and rapeseed oil on the formation of volatile fatty acids and methane in rumen and fatty acid profiles in the rumen content and muscles of lambs, Acta Vet-Beograd, 66, 373-391, 2016.

Monin, G. and Sellier, P.: Pork of low technological quality with a normal rate of muscle $\mathrm{pH}$ fall in the immediate post-mortem period: the case of the Hampshire breed, Meat Sci., 13, 49-63, 1985.

Morán, L., Andrés, S., Bodas, R., Prieto, N., and Giráldez, F. J.: Meat texture and antioxidant status are improved when carnosic acid is included in the diet of fattening lambs, Meat Sci., 91, 430-434, 2012a.

Morán, L., Rodríguez-Calleja, J., Bodas, R., Prieto, N., Giráldez, F. J., and Andrés, S.: Carnosic acid dietary supplementation at $0.12 \%$ rates slows down meat discolouration in gluteus medius of fattening lambs, Meat Sci., 90, 789-795, 2012b.

Morán, L., Andrés, S., Bodas, R., Benavides, J., Prieto, N., and Pérez, V.: Anioxidants included in the diet of fattening lambs: Effects on immune response, stress, welfare and distal gut microbiota, Anim. Feed Sci. Technol., 173, 177-185, 2012c.

Morán, L., Giráldez, F. J., Panseri, S., Aldai, N., Jordán, M. J., Chiesa, L. M., and Andrés, S.: Effect of dietary carnosic acid on the fatty acid profile and flavour stability of meat from fattening lambs, Food Chem., 138, 2407-2414, 2013.

Nair, M. N., Suman, S. P., Chatli, M. K., Li, S., Joseph, P., Beach, C. M., and Rentfrow, G.: Proteome basis for intramuscular variation in color stability of beef semimembranosus, Meat Sci., 113, 916, 2016.

Najafi, M. H., Zeinoaldini, S., Ganjkhanlou, M., Mohammadi, H., Hopkins, D. L., and Ponnampalam, E. N.: Performance, carcass traits, muscle fatty acid composition and meat sensory properties of male Mahabadi goat kids fed palm oil, soybean oil or fish oil, Meat Sci., 92, 848-854, 2012.

Navarro-Alarcon, M. and Cabrera-Vique, C.: Selenium in food and the human body: A review, Sci. Total Environ., 400, 115-141, 2008.

Nute, G. R., Richardson, R. I., Wood, J. D., Hughes, S. I., Wilkinson, R. G., Cooper, S. L., and Sinclair, L. A.: Effect of dietary oil source on the flavor and the colour and lipid stability of lamb meat, Meat Sci., 77, 547-555, 2007.

Ortuño, J., Serrano, R., Jordán, M. J., and Bañón, S.: Shelf life of meat from lambs given essential oil-free rosemary extract containing carnosic acid plus carnosol at 200 or $400 \mathrm{mg} \mathrm{kg}^{-1}$, Meat Sci., 96, 1452-1459, 2014.

Ouali, A., Gagaoua, M., Boudida, Y., Becila, S., Boudjellal, A., Herrera-Mendez, C. H., and Sentandreu, M. A.: Biomarkers of meat tenderness: Present knowledge and perspectives in regards to our current understanding of the mechanisms involved, Meat Sci., 95, 854-870, 2013.

Pérez, A. S., Ruiz, A. G., Contreras, C. M., and Ibáñez, M. D. C.: Separation and identification of sarcoplasmic proteins from hams from three white pigs crosses containing Duroc, Eur. Food Res. Technol., 216, 193-198, 2003.

Picard, B., Lebret, B., Cassar-Malek, I., Liaubet, L., Berri, L., Bihan-Duval, E., Hocquette, J. F., and Renand, G.: Recent ad- 
vances in omic technologies for meat quality management, Meat Sci., 109, 18-26, 2015.

Ponnampalam, E. N., Butler, K. L., McDonagh, M. B., Jacobs, J. L., and Hopkins, D. L.: Relationship between muscle antioxidant status, forms of iron, polyunsaturated fatty acids and functionality (retail colour) of meat in lambs, Meat Sci., 90, 297-303, 2012.

Prange, H., Juggrt, L., and Scharner, E.: Untersuchungen zur Muskelfleischqualität beim Schwein, Arch. Exp. Vet. Med., 30, 235-248, 1977.

Przybylski, W., Kaczor, D, Żelechowska, E., Jaworska, D., KajakSiemaszko, K., Boruszewska, K., and Jankiewicz, U.: Protein profile in drip loss in relation to pork quality, J. Food Sci., 80, C2320-C20326, 2016.

Ramirez, J. A., Oliver, M. A., Pla, M., Guerrero, L., Arino, B., Blasco, A., Pascual, M., and Gil, M.: Effect of selection for growth rate on biochemical, quality and texture characteristics of meat from rabbits, Meat Sci., 67, 617-624, 2004.

Ramírez-Retamal, J., Morales, R., Martínez, M. E., and de la Barra, R.: Effect of the type of pasture on the meat characteristics of Chilote lambs, Food Nutr. Sci., 5, 635-644, 2014.

Ripoll, G., Joy, M., and Muñoz, F.: Use of dietary vitamin E and selenium (Se) to increase the shelf life of modified atmosphere packaged light lamb meat, Meat Sci., 87, 88-93, 2011.

Rowe, L. J., Maddock, K. R., Lonergan, S. M., and Huff-Lonergan, E.: Oxidative environments decrease tenderization of beef steaks through inactivation of $\mu$-calpain, J. Anim. Sci., 82, 3254-3266, 2004.

Rozbicka-Wieczorek, A. J., Krajewska-Bienias, K. A., and Czauderna, M.: Dietary carnosic acid, selenized yeast, selenate and fish oil affected the concentration of fatty acids, tocopherols, cholesterol and aldehydes in the brains of lambs, Arch. Anim. Breed., 59, 215-226, doi:10.5194/aab-59-215-2016, 2016.

Santé-Lhoutellier, V., Engel, E., Aubry, L., and Gatellier, P.: Effect of animal (lamb) diet and meat storage on myofibrillar protein oxidation and in vitro digestibility, Meat Sci., 79, 777-783, 2008.

Sayd, T., Morzel, M., Chambon, C., Franck, M., Figwer, P., Larzul, C., LeRoy, P., Monin, G., Chérel, P., and Laville, E.: Proteome analysis of the sarcoplasmic fraction of pig semimembranosus muscle: implications on meat color development, J Agric. Food Chem., 54, 2732-2737, 2006.

Scheffler, T. L. and Gerrard, D. E.: Mechanisms controlling pork quality development: The biochemistry controlling postmortem energy metabolism, Meat Sci., 77, 7-16, 2007.

Schiller, K. F., Preuss, S., Kaffarnik, S., Vetter, W., Rodehutscord, M., and Bennewitz, J.: Concentration of three branched-chain fatty acids in adipose tissue does not affect meat sensory traits in crossbred and purebred German "Merinolandschaf" lambs, Arch. Anim. Breed., 58, 159-163, doi:10.5194/aab-58159-2015, 2015.
Shibata, M., Matsumoto, K., Oe, M., Ohnishi-Kameyama, M., Ojima, K., Nakajima, I., Muroya, S., and Chikuni, K.: Differential expression of the skeletal muscle proteome in grazed cattle, J. Anim. Sci., 87, 2700-2708, 2009.

Sierra, V., Fernández-Suárez, V., Castro, P., Osoro, K., VegaNaredo, I., Garcia-Macia, M., Rodriguez-Colunga, P., CotoMontes, A., and Oliván, M.: Identification of biomarkers of meat tenderization and its use for early classification of Asturian beef into fast and late tenderizing meat, J. Sci. Food Agric., 92, 27272740, 2012.

Skřivanová, E., Marounek, M., De Smet, S., and Raes, K.: Influence of dietary selenium and vitamin E on quality of veal, Meat Sci., 76, 495-500, 2007.

StatSoft, Inc.: STATISTICA (data analysis software system), version 10, www.statsoft.com, 2011.

Taylor, J. B., Marchello, M. J., Finley, T. L., Neville, T. L., Combs, G. F., and Caton, J. S.: Nutritive value and display-life attributes of selenium-enriched beef-muscle foods, J. Food Comp. Anal., 21, 183-186, 2008.

Ufaz, S. and Galili, G.: Improving the content of essential amino acids in crop plants: goals and opportunities, Plant Physiol., 147, 954-961, 2008.

Van Laack, R. I. J. M., Kauffman, R. G., and Greaser, M. I.: Determinants of ultimate $\mathrm{pH}$ of meat, 47th ICoMST, Kraków, Poland, 22-26, 2001.

Vignolla, G., Lambertini, L., Mazzone, G., Giammarco, M., Tassinari, M., Martelli, G., and Bertin, G.: Effects of selenium source and level of supplementation on the performance and meat quality of lambs, Meat Sci., 81, 678-685, 2009.

Wąsowska, I., Maia, M. R. G., Niedźwiedzka, K. M., Czauderna, M., Ramalho Ribero, J. M. C., Devillard, E., Shingfield, K. J., and Wallace, R. J.: Influence of fish oil on ruminal biohydrogenation of C18 unsaturated fatty acids, Br. J. Nutr., 95, 1199-1211, 2006.

Żelechowska, E., Przybylski, W., Jaworska, D., and SanteLhoutellier, V.: Technological and sensory pork quality in relation to muscle and drip loss protein profiles, Eur. Food Res. Technol., 234, 883-894, 2012.

Zhan, X., Wang, M., Zhao, R., Li, W., and Xu, Z.: Effects of different selenium source on selenium distributionloin quality and antioxidant status in finishing pigs, Anim. Feed Sci. Technol., 132, 202-211, 2007. 